\title{
Fermented Milk by Bifidobacterium angulatum and Infection Induced by Escherichia coli $\mathrm{O}_{157}: \mathrm{H}_{7}$ in Mice
}

\author{
${ }^{1}$ Mohaddeseh Namjoo, ${ }^{2} \mathrm{~S}$. Ali Taheri and ${ }^{3}$ Fatemeh Taheri \\ ${ }^{1}$ Department of Paramedicine, Golestan University of Medical Sciences, \\ ${ }^{2}$ University of Medical Sciences, \\ ${ }^{3}$ Department of Chemical Engineering, Gorgan, Iran
}

\begin{abstract}
Escherichia coli is the most important species in the Escherichia genus. In the recent years, haemorrhagic colitis has been associated with a strain called $E$. coli $\mathrm{O}_{157}: \mathrm{H}_{7}$. This strain is known as causative agent of bloody diarrhea and predominant cause of Haemolytic Uremic Syndrome (HUS). The aim of this study was to determine the effect of milk fermented by Bifidobacterium angulatum as a probiotic on infection induced by $E$. coli $\mathrm{O}_{157}: \mathrm{H}_{7}$ in mice. In this study, 45 mice of $6-8$ weeks age were randomly divided into 5 groups, each containing 9 mice. These groups consisted of control group $\mathrm{A}$, infected group $\mathrm{B}$, non-infected group fed by probiotic C, pre-infected group fed by probiotic D and post-infected group fed by probiotic E. Each mouse in

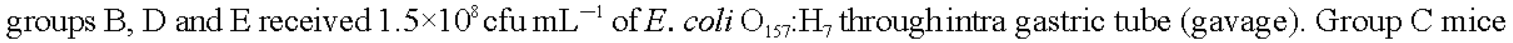
fed with $0.5 \mathrm{~mL}$ of $B$. angulatum fermented milk daily for 14 days, group $\mathrm{D}$ mice fed with $0.5 \mathrm{~mL}$ of B. angulatum fermented milk daily for 7 days post-infection and group $\mathrm{E}$ mice fed as mentioned earlier for 7 days prior to infection. Mice stools were studied for $E$. coli $\mathrm{O}_{157}: \mathrm{H}_{7}$ before getting infected and on days 2 , 4 and 7 after infection. MacConkey sorbitol agar was used to identify $E$. coli $\mathrm{O}_{157}: \mathrm{H}_{7}$ and specific antiserum against $E$. coli $\mathrm{O}_{157}$ was used for confirmation. Alive $E$. coli $\mathrm{O}_{157}: \mathrm{H}_{7}$ was not isolated in mice of control group $\mathrm{A}$ and non-infected group fed with the probiotic C. Statistical analysis showed significant differences between group $\mathrm{C}, \mathrm{B}$ and $\mathrm{D}(\mathrm{p}<0.01)$. Results showed that consumption of milk fermented by B. angulatum could shorten the duration and reduce the severity of the illness caused by B. angulatum. Further studies are needed on humans.
\end{abstract}

Key words: Escherichia coli $\mathrm{O}_{157}: \mathrm{H}_{7}$, Bifidobacterium angulatum, fermented milk, mouse, Iran

\section{INTRODUCTION}

In the recent years, Haemorrhagic colitis has been associated with a strain called $E$. coli $\mathrm{O}_{157}: \mathrm{H}_{7}$ which is known as causative agent of bloody diarrhea and predominant cause of Haemolytic Uremic Syndrome (HUS) (Asahara et al., 2004). So far, no acceptable evidence regarding use of antimicrobial agents for the treatment of disease by $E$. coli $\mathrm{O}_{157}: \mathrm{H}_{7}$ has been confirmed and it is believed that antibiotics may cause kidney failure (Asahara et al., 2004; Bomba et al., 2002).

Probiotics are microbial cell productions or parts of microbial cells with effects on human health and wellness. According to in vitro and in vivo studies of human populations and laboratory animals, several valuable properties have been reported from probiotics productions such as: resistance to intestinal pathogens, treatment and prevention of viral and bacterial diarrhea, inhibitory effect on colon cancer, preventive effect on bladder cancer, strengthen the immune system, inhibition of bacterial growth in small intestine, treatment of urinary tract and genital infections, treatment of infections caused by helicobacter pylori improvement of lactose intolerance, reduce blood cholesterol and so on (Fioramonti et al., 2003; Fooks and Gibson, 2003; Gagnon et al., 2004, 2006; Hajela et al., 2012).

Recent reports and studies concentrate on investigation of the probiotic necessary amounts in the host health. Taking probiotics such as bifidobacterium can related to survival and balance of intestine natural microflora and prevent the intestinal infections. Growth inhibition of intestinal pathogens by commercial bifidobacteriums (probiotics) is shown in laboratories (Holzapfel et al., 2001; Isolauri et al., 2002; Kim et al., 2001).

The aim of this study was to determine the effect of milk fermented by Bifidobacterium angulatum as a high consumption probiotic on infections induced by different doses of Escherichia coli $\mathrm{O}_{157}: \mathrm{H}_{7}$ in mice.

Corresponding Author: S. Ali Taheri, University of Medical Sciences, Gorgan, Iran 


\section{MATERIALS AND METHODS}

In this experimental study, the effect of fermented milk on infection induced by three different doses of Escherichia coli $\mathrm{O}_{157}: \mathrm{H}_{7}$ in mouse has been determined.

Mice regimentation: Firstly, 45 mice of 6-8 weeks age prepared from mouse laboratory, Tabriz University of Medical Sciences and get used to new environment for 7 days, under $12 \mathrm{~h}$ of light and $12 \mathrm{~h}$ dark with routine diet and free access to water and then were randomly divided into 5 groups.

Control group A: Not been exposed to the bacterium E. coli $\mathrm{O}_{157}: \mathrm{H}_{7}$ and water and food did not contain Bifidobacterium angulatum probiotic.

Infected group B: Mice infected with E. coli $\mathrm{O}_{157}: \mathrm{H}_{7}$ but did not receive probiotic.

Group C: Non-infected group fed by probiotic on days 0-7.

Group D: Fed with probiotic on days $0-7$ and were infected with $E$. coli $\mathrm{O}_{157}: \mathrm{H}_{7}$ on day 7 .

Group E: After exposure to E. coli $\mathrm{O}_{157}: \mathrm{H}_{7}$ on day 7 , received probiotic Bifidobacterium angulatum from days 7-14.

After statistical analysis of the 1st stage results, 18 mice were used to ambient under previous conditions in 2 nd and 3rd stage and were randomly divided into 2 groups: treated and control.

The 1st and 2nd group of mice were infected using esophageal catheter, $3 \times 10^{8} \mathrm{cfu} \mathrm{g}^{-1}$ and $6 \times 10^{8} \mathrm{cfu} \mathrm{mL}^{-1}$ Escherichia coli $\mathrm{O}_{157}: \mathrm{H}_{7}$ on day 0 , respectively.

According to the 1st stage, fermented milk by Bifidobacterium angulatum was added to the drinking water of treated mice but not to the control group.

Preparation of bacteria: Escherichia coli $\mathrm{O}_{157}: \mathrm{H}_{7}$ was obtained from the Microbiology Laboratory of Veterinary Faculty of Tehran University and was amplified on nutrient agar medium for $24 \mathrm{~h}$ at $37^{\circ} \mathrm{C}$ and was confirmed by IMVIC cultures and $\mathrm{O}_{157}$ antiserum. Then according to the method of Mc Farland nephelometry from formed colonies, 0.5 diluted solution containing $1.5 \times 10^{8} \mathrm{cfu} \mathrm{mL}^{-1}$ were prepared.

The $0.5 \mathrm{~mL}$ diluted solution was given to the mice in group $\mathrm{B}$ on day 0 and groups $\mathrm{D}$ and $\mathrm{E}$ on day 7 using an esophageal tube gavage.
Lyophilized Bifidobacterium angulatum PTCC is equal to 1366 was prepared by Scientific and Research Organization of Iran and as ordered by the manufacturer, first was activated in the peptonated water environment (Merck factory) for $48 \mathrm{~h}$ at $37^{\circ} \mathrm{C}$ then $5 \mathrm{~mL}$ of this medium was inoculated in $250 \mathrm{~mL}$ of sterilized milk. And the resulting milk was incubated at $37^{\circ} \mathrm{C}$ until the $\mathrm{pH}$ reaches about $80^{\circ}$ dornik.

This fermented milk was transported to the laboratory and during the study period was used as culture inoculums. To prepare the fermented milk with required Bifidobacterium angulatum, $2 \%$ of the initial culture inoculums were inoculated into sterilized milk and according to the schedule time outlined, some of resulting fermented milk was added to the drinking water of groups $\mathrm{C}, \mathrm{D}$ and $\mathrm{E}$ daily and each mouse should receive approximately $0.5 \mathrm{~mL}$ of fermented milk.

Counting the number of Escherichia coli $\mathrm{O}_{157}: \mathrm{H}_{7}$ shed in mice feces: On days 1, 3, 5, 7 and 9 before the infection, mice stool samples were prepared and tested. After physical bounding with animal's abdomen downside, fecal samples were taken and placed in sterile containers with a certain weight.

From the taken stool samples in peptonated water environment, $10^{-1}$ to $10^{-6}$ dilutions were prepared and surface cultures were prepared in MacConkey sorbitol agarand incubated for $24 \mathrm{~h}$ at $37^{\circ} \mathrm{C}$.

Then, the numbers of sorbitol-negative colonies were counted and the square of them were confirmed with $\mathrm{O}_{157}$ antiserum and the number of Escherichia coli $\mathrm{O}_{157}: \mathrm{H}_{7}$ excretion in mice faeces was counted using the following equation:

$$
\begin{aligned}
N= & \text { (Proportion of positive colonies with antiserum } \times \\
& 10 \times \text { reverse of the dilution } \times \\
& \text { No. of suspected colonies })
\end{aligned}
$$

In addition to the above experiment, the amount of water and food consumption were measured and calculated by subtracting the residual value from the amount of available meals given to each group. At the beginning and end of the experiment, mice body weights were measured and recorded and clinical symptoms were assessed in each group daily.

\section{RESULTS}

The results of the 3 stages of the study are shown in Fig. 1- 4.

A: The results of the E. coli $\mathrm{O}_{157}: \mathrm{H}_{7}$ counts and the numbers of excretion days in the first test in each group of mice, being infected with $1.5 \times 10^{8} \mathrm{cfu} \mathrm{mL}^{-1}$ doses, was 
shown in Fig. 1 and 2. Groups $\mathrm{A}$ and $\mathrm{C}$ are not shown in Fig. 1 as no isolation of E. coli $\mathrm{O}_{157}: \mathrm{H}_{7}$ were reported in them.

As was shown in Fig. 1, the number of $E$. coli $\mathrm{O}_{157}: \mathrm{H}_{7}$ shedding decreased from the inoculation time up to the nineth day. The mean $( \pm \mathrm{SD})$ of Escherichia coli $\mathrm{O}_{157}: \mathrm{H}_{7}$ was $11.53 \pm 2.81 \times 10^{5} \mathrm{cfu} \mathrm{mL}^{-1}$ in group $\mathrm{B}, 2.67 \pm 0.65 \times 10^{5}$ cfu $\mathrm{mL}^{-1}$ in group $\mathrm{D}$ and $1.47 \pm 0.57 \times 10^{5} \mathrm{cfu} \mathrm{mL}^{-1}$ in group

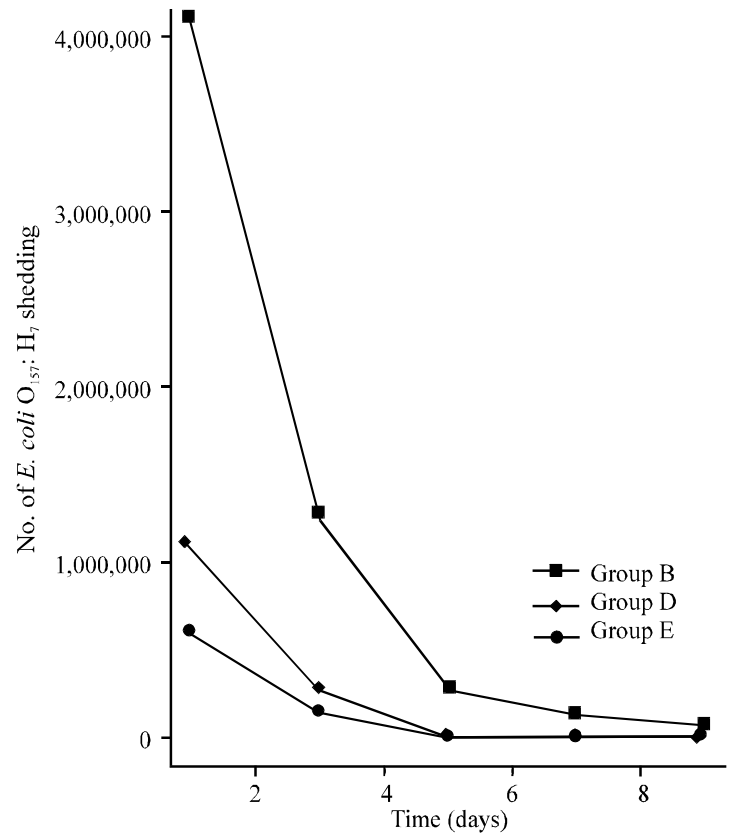

Fig. 1: No. of E. coli $\mathrm{O}_{157}: \mathrm{H}_{7}$ shedding by mice infected with a dose of $1.5 \times 10^{8} \mathrm{cfu} \mathrm{mL}^{-1}$

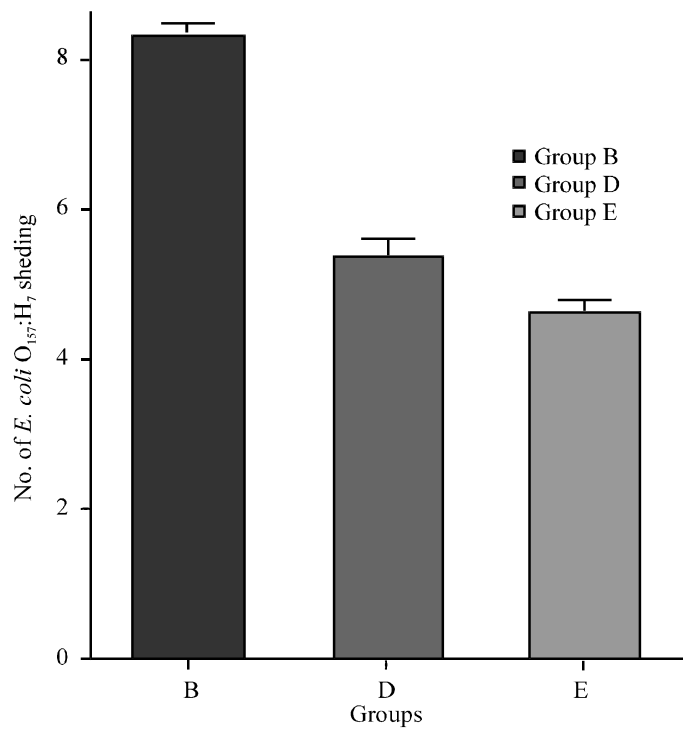

Fig. 2: Mean of shedding days of $E$. coli $\mathrm{O}_{157}: \mathrm{H}_{7}$ in mice feces
$\mathrm{E}$, during 9 days. One-way variance analysis and Tukey test showed a significantly lower rate in groups D and $\mathrm{E}$ compared to $B(p<0.01)$.

B: As shown in Fig. 2, the mean number of E. coli $\mathrm{O}_{157}: \mathrm{H}_{7}$ shedding days in mice feces was estimated 4.6 \pm 1.1 , $5.4 \pm 1.32$ and $8.33 \pm 0.95$ in groups $B, D$ and $E$, respectively. One-way variance analysis and Tukey test showed significantly lower days in group E compared to the other 2 groups $(\mathrm{p}<0.01)$.

C: Results of the 2nd stage (groups had been infected with a dose of $\left(3 \times 10^{8} \mathrm{cfu} \mathrm{mL}^{-1}\right)$ are shown in Fig. 3 .

As shown in Fig. 3, the number of E. coli $\mathrm{O}_{157}: \mathrm{H}_{7}$ shedding by treated and control groups of infected mice with a dose of $3 \times 10^{8} \mathrm{cfu} \mathrm{mL}^{-1}$ has been decreased up to the 5th day. Mean $\pm \mathrm{SD}$ of Escherichia coli $\mathrm{O}_{157}: \mathrm{H}_{7}$ shedding during 5 days of treatment and control groups, respectively was $13.11 \pm 1.55 \times 10^{5} \quad \mathrm{cfu} \mathrm{g}^{-1}$ and $20.78 \pm 3.29 \times 10^{5} \mathrm{cfu} \mathrm{g}^{-1}$. Using t-test, this mean in the treatment group was estimated significantly lower than the control group $(\mathrm{p}<0.05)$.

D: The result of the $3 \mathrm{rd}$ stage test (mice infected with a dose of $6 \times 10^{8} \mathrm{cfu} \mathrm{mL}^{-1}$ ) is shown in Fig. 4. The number of $E$. coli $\mathrm{O}_{157}: \mathrm{H}_{7}$ shedding by treated and control groups of mice infected with a dose of $6 \times 10^{8} \mathrm{cfu} \mathrm{mL}^{-1}$ has been

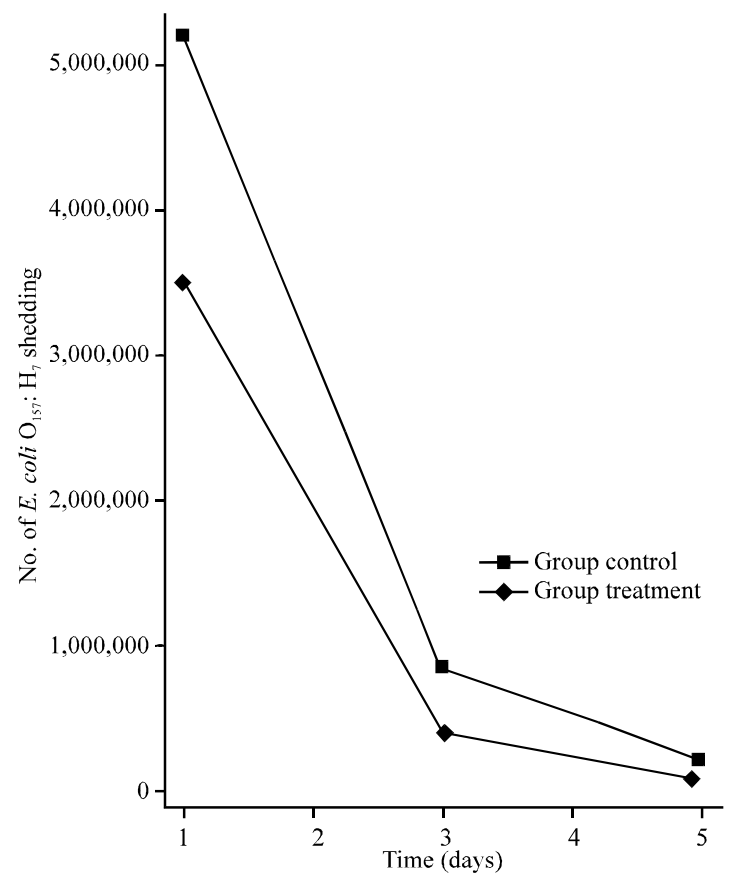

Fig. 3: No. of $E$. coli $\mathrm{O}_{157}: \mathrm{H}_{7}$ shedding by mice infected with $3 \times 10^{8} \mathrm{cfu} \mathrm{mL}^{-1}$ doses 


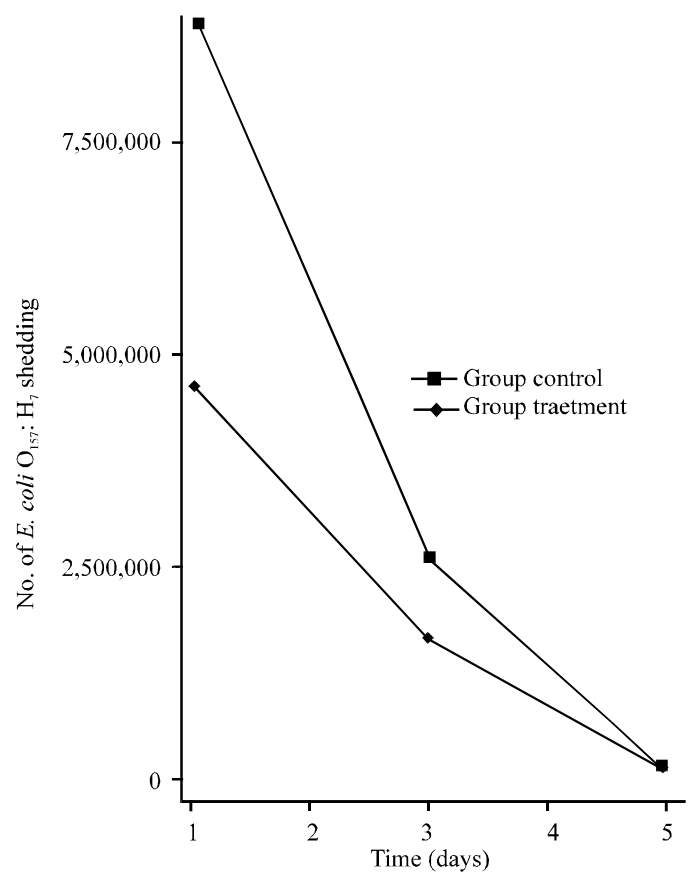

Fig. 4: No. of E.coli $\mathrm{O}_{157}: \mathrm{H}_{7}$ shed by mice infected with $6 \times 10^{8} \mathrm{cfu} \mathrm{mL}^{-1}$ doses during the study period

decreased up to the 5th day. The mean number of Escherichia coli $\mathrm{O}_{157}: \mathrm{H}_{7}$ excretion during the 5 days of in treatment and control groups were $20.56 \pm 2.03 \times 10^{5}$ and $38.11 \pm 4.17 \times 10^{5} \mathrm{cfu} \mathrm{g}^{-1}$, respectively. This was estimated significantly lower in the treatment group than the control one $(\mathrm{p}<0.01)$. It should be mentioned that no clinical symptoms had been seen in the studied groups.

\section{DISCUSSION}

Results showed that consumption of milk fermented by Bifidobacterium angulatum, either before or after infection could significantly reduce the number of $E$. coli $\mathrm{O}_{157}: \mathrm{H}_{7}$ shedding in the feces of mice infected with a dose of $1.5 \times 10^{8}$ cfu $\mathrm{mL}^{-1}$ compared with control group $(\mathrm{p}<0.01)$.

Using this type of fermented milk during the infection was shown more efficient than using probiotics pre-contamination (before), non-significantly.

As results of this study showed consumption of fermented milk before and concurrently with infection, decreased the number of days shedding $E$. coli $\mathrm{O}_{157}: \mathrm{H}_{7}$, significantly. Fermented milk with Bifidobacterium angulatum, reduced the mean number of bacteria excretion in mice infected with doses of $3 \times 10^{8}$ and $6 \times 10^{8}$ cfu $\mathrm{mL}^{-1}$ E. coli $\mathrm{O}_{157}: \mathrm{H}_{7}$, significantly.

It has been reported that $\mathrm{pH}$ reduction of intestinal environment by the production of short chain volatile fatty acids, consumption of nutrients and requirement for bacteria and production of specific antimicrobial compounds such as bacteriocins are the mechanisms of lactobacilli and bifidobacters inhibitory effect on pathogen bacteria (Lema et al., 2001).

Holzapfel et al. (2001) suggested that although the probiotic strains are able to produce bacteriocins but their role in inhibiting growth of pathogens in vivo would be limited because bacteriocins only had the inhibitory effect on very close strains (Mirzaii et al., 2010).

Melanie studied inhibitory effect of some strains of bifidobacter on $E$. coli $\mathrm{O}_{157}: \mathrm{H}_{7}$ and results showed that preventing the binding of Escherichia coli to Caco-2 cells by bifidobacters was the main inhibitory factor on escherichia (Molbak et al., 2002).

Lema et al. (2001) showed that food supply of lambs infected by Streptococus faecium or a mixture of S. faecium, L. acidophilus, L. casei, L. fermentum and $L$. lantarum in diet could reduce the overall amount of $\mathrm{O}_{157}: \mathrm{H}_{7} E$. coli fecal excretion and also could improve performance and meat production processes in animals (Ouwehand et al., 2002).

Shu and Gill (2001) reported that feeding with the probiotic L. rhamnosus can reduce the survival of the E. coli $\mathrm{O}_{157}: \mathrm{H}_{7}$ contamination in mice and suggested hat this decrease can be associated with increased homoral and cellular immune responses (Kim et al., 2001).

Fioramonti reported that probiotics have little effects on digestive tract physiology and the main function of probiotics can be summarized as strengthening and renewal of the intestinal mucosal barrier against harmful agents (Qi et al., 2011).

Gagnon reported that isolated bifidobacterium from fresh feces could be beneficial in improving probiotic formulation regards to their protection against $E$. coli $\mathrm{O}_{157}: \mathrm{H}_{7}$ contamination (Molbak et al., 2002).

Gagnon stated that the severity of E. coli $\mathrm{O}_{157}: \mathrm{H}_{7}$ infection can reduce with pasture of mice with probiotic B. thermacidophilum RBL 71 and this probiotic had suggested as a selected and a suitable candidate for the prevention of intestinal infection in humans (Shu and Gill., 2001).

\section{CONCLUSION}

It could be concluded that consumption of fermented milk with Bifidobacterium angulatum reduces the mean number of $E$. coli $\mathrm{O}_{157}: \mathrm{H}_{7}$ and its time of disposal in infected mice.

\section{REFERENCES}

Asahara, T., K. Shimizu, K. Nomoto, T. Hamabata, A. Ozawa and Y. Takeda, 2004. Probiotic bifidobacteria protect mice from lethal infection with Shiga toxinproducing Escherichia coli 0157 : H7. Infect. Immun., 72: $2240-2247$. 
Bomba, A., R. Nemcova, D. Mudronova and P. Guba, 2002. The possibilities of potentiating the efficacy of probiotics. Trends Food Sci. Technol., 13: 121-126.

Fioramonti, J., V. Theodorou and L. Bueno, 2003. Probiotics: What are they? What are their effects on gut physiology? Best Pract. Res. Clin. Gastroenterol., 17: $711-724$.

Fooks, L.J. and G.R. Gibson, 2003. Mixed culture fermentation studies on the effects of synbiotics on the human intestinal pathogens Campylobacter jejuni and Escherichia coli. Anaerobe, 9: 231-242.

Gagnon, M., E.E. Kheadr, G. Le Blay and I. Fliss, 2004. In vitro inhibition of Escherichia coli 0157 : $\mathrm{H} 7$ by bifidobacterial strains of human origin. Int. J. Food Microbiol., 92: 69-78.

Gagnon, M., E.E. Kheadr, N. Dabour, D. Richard and I. Fliss, 2006. Effect of Bifidobacterium thermacidophilum probiotic feeding on enterohemorrhagic Escherichia coli 0157: H7 infection in BALB/c mice. Int. J. Food Microbiol., 111: 26-33.

Hajela, N., G.B. Nair, P. Abraham and N.K. Ganguly, 2012. Health impact of probiotics-vision and opportunities. Gut Pathogens, Vol. 4. 10.1186/1757-4749-4-1

Holzapfel, W.H., P. Haberer, R. Geisen, J. Bjorkroth and U. Schillinger, 2001. Taxonomy and important features of probiotic microorganisms in food and nutrition. Am. J. Clin. Nutr., 73: 365S-373S.
Isolauri, E., P.V. Kirjavainen and S. Salminen, 2002. Probiotics: A role in the treatment of intestinal infection and inflammation? Gut., 3: 54-59.

Kim, S.H., S.J. Yang, H.C. Koo, W.K. Bae and J.Y. Kim et al., 2001. Inhibitory activity of Bifidobacterium longum HY8001 against Vero cytotoxin of Escherichia coli O157: H7. J. Food Prot., 64: 1667-1673.

Lema, M., L. Williams and D.R. Rao, 2001. Reduction of fecal sheeding of enterohermoraggic Escherichia coli O157:H7 in lambs by feeding microbial feed supplement. Small Ruminant Res., 39: 31-39.

Mirzaii, H., M.R. Nahaii, S.A. Taheri and S.A. Nakhjavani, 2010. Probiotics and introduction to their role in human health. J. Tabriz Univ. Med. Sci., 32: 80-85.

Molbak, K., P.S. Mead and P.M. Griffin, 2002. Antimicrobial therapy in patients with Escherichia coli 0157: H7 infection. J. Am. Med. Assoc., 288: 1014-1016.

Ouwehand, A.C., S. Salminen and E. Isolauri, 2002. Probiotics: An overview of beneficial effects. Antonie Van Leeuwenhoek, 82: 279-289.

Qi, H., Z. Zhong, H.X. Zhou, C.Y. Deng and H. Zhu et al., 2011. A rapid and highly sensitive protocol for the detection of Escherichia coli $0157: \mathrm{H} 7$ based on immunochromatography assay combined with the enrichment technique of immunomagnetic nanoparticles. Int. J. Nanomed., 6: 3033-3039.

Shu, Q. and H.S. Gill, 2001. A dietary probiotic (Bifidobacterium lactis HN019) reduces the severity of Escherichia coli O157:H7 infection in mice. Med. Microbiol. Immunol., 189: 147-152. 